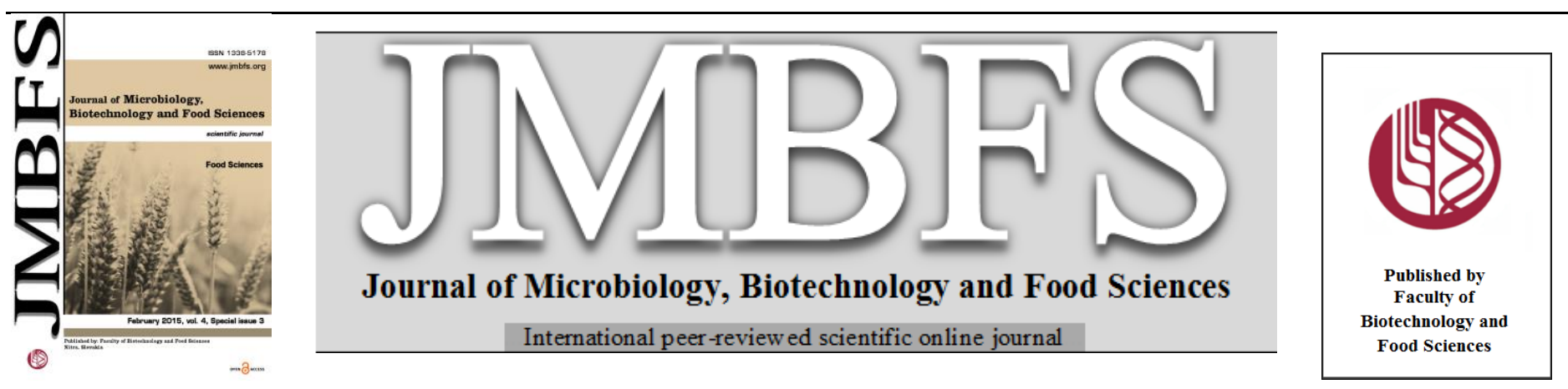

\title{
NITRATES IN INDIVIDUAL GROUNDWATER RESOURCES IN NITRA AND THEIR POSSIBLE RISKS TO THE POPULATION
}

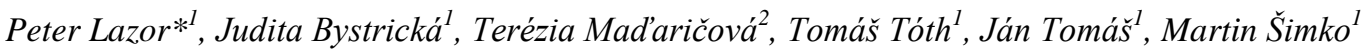

Address(es): doc. Mgr. Ing. Peter Lazor, PhD.

${ }^{1}$ Slovak University of Agriculture in Nitra, Faculty of Biotechnology and Food Sciences, Department of Chemistry, Tr. A. Hlinku 2, 94976 Nitra, Slovakia, phone number: +4213764345.

${ }^{2}$ The National Institute of Cardiovascular Diseases, Department of Cardiovascular Medicine, Pod Krásnou hôrkou 1, 83348 Bratislava III, Slovakia, phone number: +421259320111.

*Corresponding author: Peter.Lazor@uniag.sk

doi: 10.15414/jmbfs.2015.4.special3.99-101

\section{ARTICLE INFO}

Received 20.11. 2014

Revised 27. 11. 2014

Accepted 28. 11. 2014

Published 2. 2. 2015

Regular article

OPEN $\partial_{\text {ACCESS }}$

\section{ABSTRACT}

The content of nitrates $\left(\mathrm{NO}_{3}^{-}\right)$were assessed in the period 2012 - 2013 in samples taken from individual groundwater sources (Svorad's spring, Puškin's spring, spring on Pivoňková street, spring on Mriánska dolina, spring Šindolka and spring Buganka) in the administrative area of Nitra and Zobor, also used for human consumption. The content of $\mathrm{NO}^{3-}$ were assessed by Photocolorimetric method. We also evaluate the results achieved in relation to the current legislation of the area.

From the result of the performed analyzes during the whole period shows that the average concentration $\mathrm{of}^{\mathrm{NO}_{3}}{ }_{3}$ represented in samples of water from the source Svorad's spring $12,1 \mathrm{mg} \cdot \mathrm{dm}^{-3}$, Puškin's spring $14,6 \mathrm{mg} \cdot \mathrm{dm}^{-3}$, from spring St. Martina $117,0 \mathrm{mg} \cdot \mathrm{dm}^{-3}$, from spring on Pivoňkova street $6,4 \mathrm{mg} \cdot \mathrm{dm}^{-3}$, from spring Šindolka $39,5 \mathrm{mg} \cdot \mathrm{dm}^{-3}$ and spring Buganka $101,7 \mathrm{mg} \cdot \mathrm{dm}^{-3}$.

The nitrate concentration exceeded the limit value in $16 \%$ of cases in 2012 and it was $17 \%$ of cases in 2013. Based on the measured values, therefore we do not recommend to use the water for human consumption from springs Buganka and St. Martina at the endpoint.

Keywords: Groundwater, quality, nitrates, city of Nitra

\section{INTRODUCTION}

Until recently, the issue of groundwater was mainly focused on their use as a source of drinking water (about $75 \%$ of European citizens are dependent on groundwater for drinking water), and as an important resource for industry (cooling purposes) and agriculture (irrigation).

Groundwater is an irreplaceable part of the hydrological cycle and a key element in maintaining wetlands and flows in rivers during dry periods. It represents a basic drain (permanent year-round inflow to rivers) to surface hydrological systems, many of which are used as a source of water, or for recreational purposes (Lanz, 2001). The groundwater constitutes more than $50 \%$ of the average annual flow during dry periods and the amount can exceed $90 \%$ in many European rivers (Bodiš, 2010). The result is that the deterioration of groundwater quality may have direct effects on surface water and terrestrial ecosystems. Since groundwater flow is relatively slow, the effects of anthropogenic activities may be long-term (Tölgyessy et al., 2000).

The pollution caused by several decades ago as agriculture, industry, or other activities may threaten groundwater quality today, and in some cases even many generations in the future (Pado, 2001).

We can also say that the groundwater is "hidden resource", which is in quantitative terms more significant than surface water, while it is much more difficult to protect, monitor and eliminate pollution because of its inaccessibility. This "hidden" character is also the reason that the consequences of pollution are difficult to locate, describe and analyze (Bouchard, 2009; Mike, Shand, 2011). Research shows that pollution from domestic, agricultural and industrial sources, despite of progress in some areas, still one of the main issues that impact on groundwater either directly through runoff processes or indirectly, through transfer of nitrate, whose content now exceeds Directive specified limit value in about one third of groundwater reserves in Europe (Bouchard, 2009). In European countries, the percentage of the population moves using the drinking water containing nitrate over $50 \mathrm{mg} \cdot \mathrm{dm}^{-3}$ in the range 0.5 to $10 \%$, which is nearly 10 million people (Mike, Shand, 2011).

We use for drinking water in Slovakia underground water $(82.2 \%)$ and surface water $(17.8 \%)$. Largest natural reservoir of groundwater in Slovakia and Central
Europe is Žitný ostrov with usable amount of about $204001 . \mathrm{s}^{-1}$. In Bratislava, Trnava and Nitra are for a drinking water supply used only underground water sources. In other regions are for supply the population with drinking water used underground and surface water sources (Krč et al., 2007).

The city of Nitra (MŽP SR, 2012) is supplied from the water supply group of Nitra (districts Chrenová, Zobor, Staré Mesto - part Janíkovce) and water supply group Jelka - Galanta - Nitra (Staré mesto - part, urban parts Diely, Párovské Háje, Kynek, Mlynárce, Klokočina, Čermáň, Dolné a Horné Krškany).

Objective of this work was to gain knowledge about the quality of existing groundwater resources and demonstrably used for human consumption for drinking (adults or babies) in the administrative area of Nitra and Zobor, in terms of nitrate $\left(\mathrm{NO}_{3}{ }^{-}\right)$with reference to their potential health risks.

We chose for meeting the goals of groundwater resources: Svorad's spring, Puškin's spring, spring on Pivoňkova street, spring on Mriánska dolina, spring Šindolka and Buganka in the period of 2012 and 2013.

\section{MATERIAL AND METHODS}

Relative to the fact that at present does not exist any available literature also data sources dealing with the issue of groundwater quality in the city of Nitra with a specific analytical outputs to the population, we therefore referred the issues solved in our work.

We took water samples intended for chemical analysis into polyethylene sample containers of $500 \mathrm{~cm}^{3}$, which we first rinsed with water and then filled up to the cap. The total nitrate content were assessed by Photocolorimetric method using UV mini 1240 PL

\section{RESULTS AND DISCUSSION}

We collected monthly and define the content of nitrate $\left(\mathrm{NO}_{3}^{-}\right)$in groundwater samples from their individual sources in the period 2012 - 2013. The results were processed by the figure 1 and 2 , which show that: 


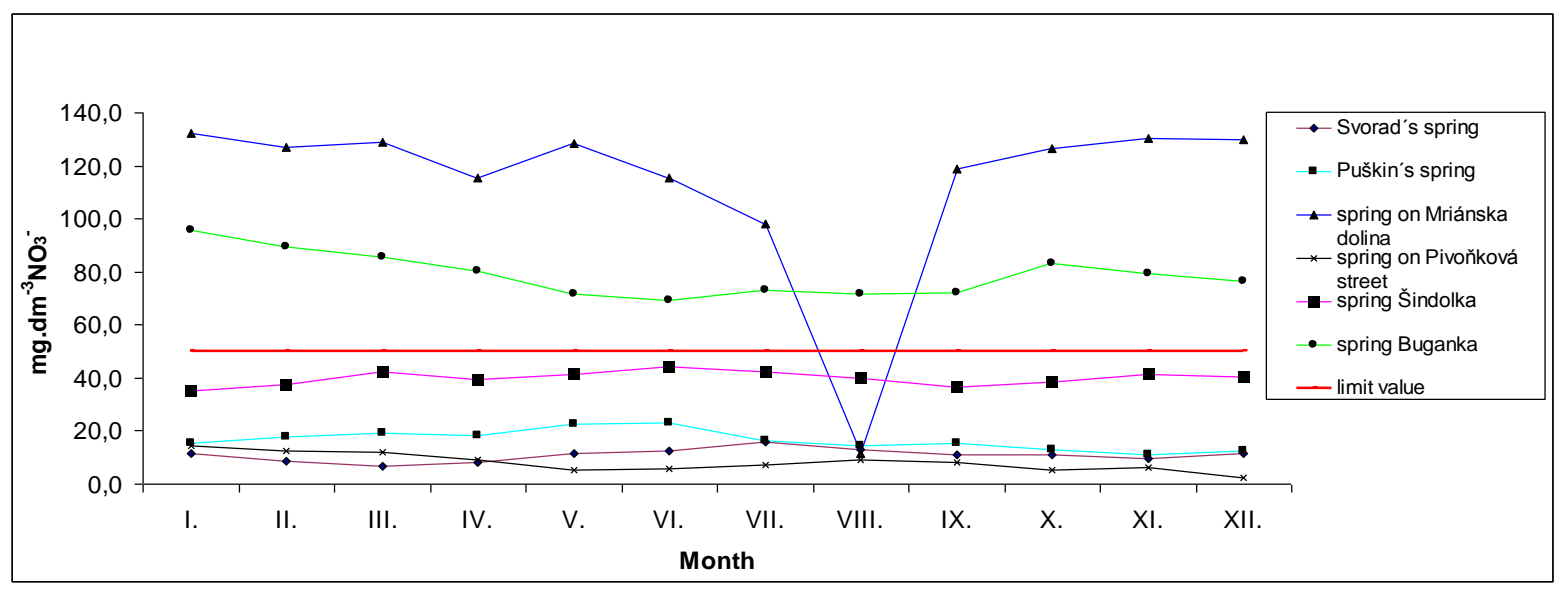

Figure 1 The measured nitrate concentrations in groundwater in 2012 compared with the limit value

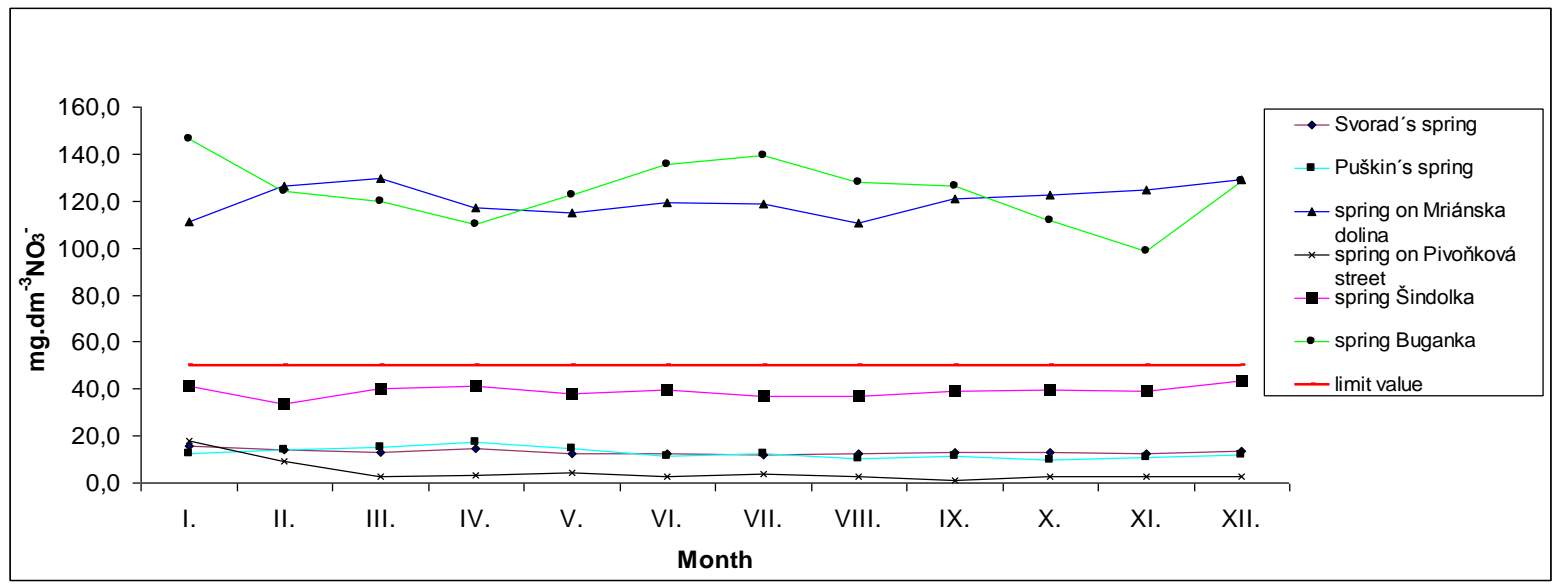

Figure 2 The measured nitrate concentrations in groundwater in 2013 compared with the limit value

Svorad's spring ( $\left.\varphi=48^{0} 20^{\prime} 47^{\prime \prime}, \lambda=18^{0} 05^{\prime} 27^{\prime \prime}\right)$ is located at the highest altitude (305 $\mathrm{m}$ asl) from all sources in the administrative area Zobor. Located in the forest, near the sanatorium under the hill Zobor $(586.9 \mathrm{~m}$ asl). Seepage water using PE pipe with a diameter of $110 \mathrm{~mm}$. During the year 2012, measured nitrate levels varied between $12.0 \mathrm{mg} \cdot \mathrm{dm}^{-3}$ (July) to $15.8 \mathrm{mg} \cdot \mathrm{dm}^{-3}$ (January). We found the minimum nitrate content of $6.7 \mathrm{mg}_{\mathrm{dm}} \mathrm{dm}^{-3}$ (March) to a maximum of 15.8 mg.dm ${ }^{-3}$ (July) in 2013.

It is generally believed that the content of $\mathrm{NO}_{3}{ }^{-}$is in groundwater in natural conditions mainly controlled by the activity of microorganisms, that is, in particular nitrifying and denitrification processes. Precipitation water nitrate concentrations are low in Slovakia, averaging $2.65 \mathrm{mg} . \mathrm{dm}^{-3}$ (Bodiš et al., 2000). In soil water $\mathrm{NO}_{3}{ }^{-}$concentration is generally increasing, mainly due to the biochemical transformation of ammonium $\left(\mathrm{NH}_{4}{ }^{+}\right)$present in the source (mainly rainfall) waters (Bodiš, 2010).

The burden of population from drinking water containing chemical health risk is assessed on the basis of the highest detected concentration detected frequency of exceedances of limit values and comparing the tolerable daily intake. If the quality of drinking water in accordance with the requirements of Government Regulation no. 354/2006 Coll., then would not the lifelong intake of 2 liters a day should not be influenced negatively population health. In higher concentrations may affect the enzymes of the digestive system, absorption of certain nutrients, metabolism of vitamin A and thyroid function (EFSA, 2010).

Puškin's spring is also located very close to Kláštorská street $\left(\varphi=48020^{\prime} 85^{\prime \prime}, \lambda=\right.$ $\left.18005^{\prime} 16^{\prime \prime}\right)$, amounting to $240 \mathrm{~m}$ asl. It is easily accessible, but the yield is low. We found minimum content in October $\left(9.6 \mathrm{mg} \cdot \mathrm{dm}^{-3}\right)$ to $17.3 \mathrm{mg} . \mathrm{dm}^{-3}$ in April during the period 2012. The content ranged from $11.2 \mathrm{mg} . \mathrm{dm}^{-3}$ (October) to 23.1 mg. dm ${ }^{-3}$ (June) evaluated in 2013.

Nitrates are in the human body after following oral ingestion rapidly and completely absorbed in the upper small intestine and rapidly distributed in the body. Approximately $25 \%$ is secreted into saliva, which are partly reduced to nitrite by oral microflora. Bacterial reduction of nitrate $\left(\mathrm{NO}_{3}{ }^{-}\right)$to nitrite $\left(\mathrm{NO}_{2}{ }^{-}\right)$ may take place in other parts of the digestive tract other than the stomach, where it occurs only at a reduced acidity (Abernal et al., 2004). Nitrates have low toxicity and non-reducing environment and low concentrations are not for adult and for human beings harmful. However, in certain circumstances, it can be reduced to nitrites, which are toxicologically significantly more dangerous (Beresford, 1995).
Source sv. Martina is right at the road between the family homes in Martin's valley ( $\left.\varphi=48019^{\prime} 20^{\prime \prime}, \lambda=18006^{\prime} 82^{\prime \prime}\right)$, amounting to $194 \mathrm{~m}$ asl with the shelter built from bricks and with wooden roof. In terms of measured concentrations of $\mathrm{NO}_{3}{ }^{-}$in 2012 has a minimum of $110.4 \mathrm{mg}^{-\mathrm{dm}^{-3}}$ in August, up to the extreme value of $129.8 \mathrm{mg} \cdot \mathrm{dm}^{-3}$ in March. We measured a minimum of nitrates in January, $201311.5 \mathrm{mg} \cdot \mathrm{dm}^{-3}$ to $132.4 \mathrm{mg}^{-\mathrm{dm}^{-3}}$ (January). It can be states in connection with such detected high levels of $\mathrm{NO}_{3}{ }^{-}$in the samples that in terms of toxicological and health assessment is a particular risk group pediatric population, which is characterized by unique and different routes of exposure (Erkekoglu, Baydar, 2009). In proportion to body weight receive a higher volume of fluid than older children and adults, their dynamic physiological development, longer life expectancy, and thus longer exposure.

Toxic effects (especially in children) are given mainly by reduction of nitrite and subsequent reaction of nitrite with hemoglobin. This occurs nitrate alimentary methemoglobinemia namely oxidation of $\mathrm{Fe}^{2+}$ to $\mathrm{Fe}^{3+}$ to convert hemoglobin $(\mathrm{Hb})$ to a dark brown methemoglobin (MetHb), which is unable to carry oxygen (Darracq, Daubert, 2007). Clinical manifestations of reduced oxygen transport in the body mostly appears after exceeding $10 \%$ MetHb concentration. This is reflected in gray-blue discoloration of the skin around the mouth and ends of fingers and nose (cyanosis). When MetHb content is above $25 \%$ it occurs weakness, increased heart rate and breathing, diarrhea, at 50-60\% MetHb it can lead to death. The normal concentration MetHb in man is within $2 \%$, in infants up to 3 months of age within 3\% (Kratochvíl et al., 2010).

Spring on Pivoňková street ( $\left.\varphi=48020^{\prime} 73^{\prime \prime}, \lambda=18005^{\prime} 84^{\prime \prime}\right)$, is in a plantation forest on the left, under Kláštotrska street towards Zobor, at an altitude of $260 \mathrm{~m}$ asl. We measured concentrations of nitrate varied from $1.3 \mathrm{mg}^{-\mathrm{dm}^{-3}}$ (Septemper) to 17.7 mg.dm ${ }^{-3}$ (January) during the period 2012. We determined in samples from this source minimum nitrate content of $2.4 \mathrm{mg} . \mathrm{dm}^{-3}$ (December) to a maximum of $14.6 \mathrm{mg} \cdot \mathrm{dm}^{-3}$ (January) in 2013.

The formation of nitrate alimentary methemoglobinemia shall apply in particular factors such as water containing inaccessible quantity of nitrate, the $\mathrm{pH}$ of gastric juice, bacterial flora upper gastrointestinal tract reducing nitrates, nitrites absorption from the gastrointestinal tract into the blood, the effect of reducing enzyme system methemoglobin to hemoglobin and probably impact of fetal hemoglobin (Pizingerova et al., 2011).

Spring Šindolka is located on Orava street ( $\left.\varphi=48019^{\prime} 50^{\prime \prime}, \lambda=18005^{\prime} 00^{\prime \prime}\right)$ and it is maintained and roofing. It is the lowest altitude of $158 \mathrm{~m}$ asl from the assessment of groundwater resources. It is a significant power of flow throughout 
the year and seepage water was using an iron pipe with a diameter of $50 \mathrm{~mm}$. We found minimum content of $\mathrm{NO}_{3}{ }^{-}$in February $\left(33.5 \mathrm{mg} . \mathrm{dm}^{-3}\right)$ to $43.6 \mathrm{mg} \cdot \mathrm{dm}^{-3}$ in December in terms of the reporting period in 2012. We found that the nitrate

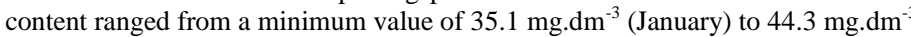
(June) in 2013.

Spring Buganka ( $\left.\varphi=48019^{\prime} 50 ", \lambda=18006^{\prime} 04 "\right)$, located on the street Lord's Valley, on private property at an altitude of $214 \mathrm{~m}$ asl, but it is open to the public. We measured minimum content of nitrates during 2012 from samples we took in November $\left(98.9 \mathrm{mg} . \mathrm{dm}^{-3}\right.$ ) to a maximum of $146.3 \mathrm{mg} \cdot \mathrm{dm}^{-3}$ in the month of January Evaluated in 2013, this content ranged from $69.1{\mathrm{mg} . \mathrm{dm}^{-3}}^{-3}$ in June to 95.8 mg.dm ${ }^{-3}$ (January). All year above average levels of nitrates are risky not only for adults but especially for children. In general, the most sensitive part of the population are just infants under 3 months of age who are at risk when preparing baby food from water containing nitrate (Kožišek, 2007). They have several causes of a higher sensitivity. This is a larger proportion of fetal hemoglobin which is easily oxidized to the enzyme deficiency MetHb and MetHb - reductase which reduces back MetHb to $\mathrm{Hb}$ (Savino et al., 2006). Another cause may be higher $\mathrm{pH}$ in the stomach, allowing bacterial colonization and reduction of nitrate to nitrite. Formation of nitrites, and thus the risk of methemoglobinemia is increased in infections of the digestive tract, which are more common in children (Erkekoglu, Baydar, 2009). Another more sensitive population groups in the formation of MetHb are pregnant women and people with deficiency of glucose6-phosphate dehydrogenase or MetHb reductase and people with reduced stomach acidity (achlorhydria, atrophic gastritis).

Determined the average nitrate levels found during the whole period 2012

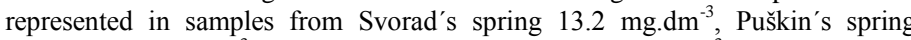
mg.dm 12.7 mg.dm ${ }^{-3}$, from spring St. Martina $120.4 \mathrm{mg} . \mathrm{dm}^{-3}$, from spring on Pivoňková street $4.6 \mathrm{mg} \cdot \mathrm{dm}^{-3}$, spring Šindolka $39.1 \mathrm{mg} \cdot \mathrm{dm}^{-3}$ and spring Buganka $124.2 \mathrm{mg} \cdot \mathrm{dm}^{-3}$. In addition to creating methemoglobinemia, high nitrate concentrations, which reduced to nitrite, causing reaction with secondary and tertiary amines, which are present almost everywhere (vegetables, meat, dairy and grain products, eggs, beer and wine, medicines, pesticides, etc.) creation of nitrosamines (Murone et al., 2005). It has been shown that nitrosamines are able to induce tumor formation in all organs of the body, particularly the gastrointestinal tract, urinary bladder and lymphatic system, with the exception of bone (Beresford, 1995).

The average nitrate content found in 2013 were in samples of water from Svorad's spring 10.9 mg.dm ${ }^{-3}$, Puškin's spring $16.5 \mathrm{mg}^{-\mathrm{dm}^{-3}}$, from spring St Martina $113.6 \mathrm{mg} . \mathrm{dm}^{-3}$, from spring on Pivoňková street $8.2 \mathrm{mg} . \mathrm{dm}^{-3}$, spring Šindolka $39.9 \mathrm{mg} \mathrm{dm}^{-3}$ and spring Buganka $79.1 \mathrm{mg}^{-\mathrm{dm}^{-3}}$

Legal context provides the requirements for drinking water quality and its control constitutes $\S 11$ of Act No.126 / 2006 Coll. on public health and on amendments to certain laws, and the government resolution. 354/2006 Coll., setting out the requirements for water intended for human consumption and control the quality of water intended for human consumption.

We found that the limit was exceeded in samples of water from the spring of 2012 Buganka an average of $74.2 \mathrm{mg} . \mathrm{dm}^{-3}$ and spring St. Martina $70.4 \mathrm{mg} . \mathrm{dm}^{-3}$ In the period 2013, the limit was exceeded in samples of water from spring St. Martina $63.6 \mathrm{mg} \cdot \mathrm{dm}^{-3}$ and spring Buganka $29.1 \mathrm{mg} \cdot \mathrm{dm}^{-3}$ during comparing the measured results of the average nitrate with current legislation, which provides drinking water maximum limit of $50 \mathrm{mg}^{-\mathrm{dm}^{-3}}$ (graph 1,2) on the basis of indirect toxic effects of nitrates in the human body (especially for infants).

These increased concentrations are the result of agricultural activity or they are created by action of nitrifying bacteria. Biochemical processes in soils are controlled mainly by suitable climatic conditions in groundwater cycle and in general, the activity of microorganisms is more intense at lower altitudes due to higher average temperatures affecting these processes. Important role in $\mathrm{NO}_{3}$ concentration fluctuations are therefore the seasonal changes in temperature, which in practice excludes biochemical reactions in the winter.

Clearly, the greatest impact on the chemical composition and content of nitrates in groundwater have point and diffuse sources of pollution that makes them various degree of anthropogenic influence. Manifestation of these effects can be up to multiple increase in nitrate levels compared to required levels. Also nitrates are stable only in oxic conditions that change with the increasing depth of reduction. Those could be caused mainly by the position of the source in relation to fertilization and spraying used in the surrounding gardens, but also the depth of the source. Therefore, use of water for human consumption from the point of view of the sources of nitrates is not recommended for drinking.

\section{CONCLUSION}

We determined the content of nitrate $\left(\mathrm{NO}_{3}{ }^{-}\right)$in water samples taken from groundwater sources in the administrative area of Nitra and Zobor, which is also used for human consumption in the period 2012 - 2013. From the experimental results obtained 144 analysis has shown that:

the total content of nitrates, that enter the groundwater due to environmental pollution, agricultural activity, or they are created by nitrification activity of bacteria ranged on average throughout the period in samples from Svorad's spring 10.9 to $13.2 \mathrm{mg} . \mathrm{dm}^{-3}$, Puškin's spring 12.7 to $16.5 \mathrm{mg} . \mathrm{dm}^{-3}$, from spring St. Martina from 113.6 to $120.4 \mathrm{mg}^{\mathrm{dm}}{ }^{-3}$, from spring on Pivoňková street 4.6 to
$8.2 \mathrm{mg} \cdot \mathrm{dm}^{-3}$, spring Šindolka 39.1 to $39.9 \mathrm{mg} \cdot \mathrm{dm}^{-3}$ and spring Buganka 79.1 to $124.2 \mathrm{mg} . \mathrm{dm}^{-3}$.

Nitrates $\left(\mathrm{NO}_{3}^{-}\right)$in the human are absorbed in the upper small intestine and rapidly distributed in the body and subsequently reduced to nitrites $\left(\mathrm{NO}_{2}^{-}\right)$which are toxicologically considerably more dangerous as they react with hemoglobin and thus there is the formation of nitrate alimentary methemoglobinemia.

We found that the limit was exceeded a total of 47 times throughout the period, during comparing the measured results with the current legislation on a given section and the highest limit value of nitrates in water intended for human consumption.It was on average $74.2 \mathrm{mg} . \mathrm{dm}^{-3}$ in the samples of water from spring

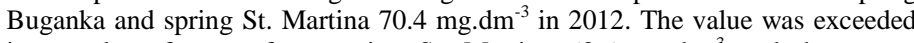
in samples of water from spring St. Martina $63.6 \mathrm{mg} \cdot \mathrm{dm}^{-3}$ and the source Buganka $29.1 \mathrm{mg} \cdot \mathrm{dm}^{-3}$ in the period 2013.

In terms of total average content of nitrate, groundwater from those sources which the highest limit value in this parameter failed to comply, for drinking purposes is not recommended.

Acknowledgments: This work was supported by the project VEGA 1/0290/13 and VEGA 1/0027/12

\section{REFERENCES}

ABERNAL, R., WISE, R., WRIGHT, S. 2004. Acquired Methemoglobinemia: A Retrospective Series of 138 Cases at 2 Teaching Hospitals. Medicine, 83(5), 265273.

BERESFORD, S. 1995. Is nitrate in the drinking water associated with the risk of cancer in the urban U.K. International Journal of Epidemiology, 14(1), 57-63. BODIŠ, D. 2010: Pozad'ová koncentrácia vybraných ukazovatel'ov v povrchovej a podzemnej vode Slovenska. Štátny geologický ústav Dionýza Štúra Bratislava, 56 s. ISBN 978-80 89343-43-0.

BODIŠ, D., LOPAŠOVSKÁ, M., LOPAŠOVSKÝ, K. 2000. Chemické zloženie snehovej pokrývky na Slovensku - výsledky 25-ročného pozorovania. Podzemná voda č.2, X. Slovenská hydrogeologická konferencia, Herl'any, 162-173.

BOUCHARD, A. 2009. Nitrate contamination of groundwater: sources and potential health effects. Pediatric health center : London, 150 p. ISSN 1992-6197 DARRACQ, M., DAUBERT, G. 2007. Cyanotic toddler. Pediatric Emergency Care, 23(3), 195-199.

EFSA. 2010. Panel on Contaminants in the Food Chain (CONTAM). Statement on possible public health risks for infants and young children from the presence of nitrates in leafy vegetables. EFSA Journal, 12(1935), 1-42.

ERKEKOGLU, P., BAYDAR, T. 2009. Evaluation of nitrite contamination in baby foods and infant formulas marketed in Turkey. International Journal of Food Sciences and Nutrition, 60(3), 206-209.

KOŽIŠEK, F. 2007. Je vodovodni voda vhodna pro připravu kojenecke stravy? Praktický lékar̆ 87(4), 224-227.

KRATOCHVÍL， J, MARTINKOVÁ, V., MASOPUST, J. 2010 Methemoglobinemie. Urgentni medicina 13(2), 33 - 34.

KRČ, R., IVANOVÁ, L., KRIŽANOVÁ, H., 2007. Grafické zobrazenie časových zmien vybraných ukazovatel'ov kvality povrchových vôd v Slovenskej republike. Správa. SHMÚ, Bratislava, $125 \mathrm{~s}$.

LANZ, K. 2001. Príručka: European Environment Bureau (EEB) o vodohospodárskej politike EÚ podl'a Rámcovej smernice o vodách. Bratislava : REC pre krajiny strednej a východnej Európy, $53 \mathrm{~s}$.

MIKE, E., SHAND, P. 2011. Natural Groundwater Quality. Geological Society : London. 488 p. ISBN: 978-1-4051-5675-2.

MURONE, A, STUCKI, P., ROBACK, M. 2005. Severe Methemoglobinemia due to food intoxication in infants. Pediatric Emergency Care 21(8), 536-538. MŽP SR. 2012. Charakteristika verejných vodovodov podl'a akciových spoločností. MŽP SR : 2012. 124 s.

PADO, R. 2001. Kvalita povrchových vôd na Slovensku 1999-2000. Bratislava : SHMÚ. $490 \mathrm{~s}$.

PIZINGEROVA, K., FREMUTH, J., ŠA ŠEK, L. 2011. Akutni methemoglobinemie - zavažna alimentarni intoxikace zeleninou koupenou na trhu. Pediatra pre prax, 12(5), 216-219.

SAVINO, F., MACCARIO, S., GUIDI, C. 2006. Methemoglobinemia Caused by the Ingestion of Courgette Soup Given in Order to Resolve Constipation in Two Formula-Fed Infants. Annals of Nutrition and Metabolism, 50(4), 368-371. http://dx.doi.org/10.1159/000094301

TÖLGYESSY, J., HARANGOZÓ, M., DAXNEROVÁ, O. 2000. Monitoring životného prostredia. Univerzita Mateja Bela : Banská Bystrica. $143 \mathrm{~s}$. 